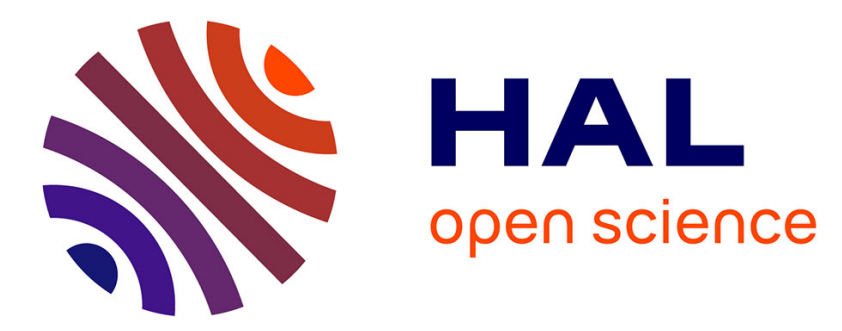

\title{
Calibration of the osmotic technique of controlling suction with respect to temperature using a miniature tensiometer
}

Anh Minh A.M. Tang, Yu-Jun Cui, Li-Xin Qian, Pierre Delage, Wei-Min Ye

\section{To cite this version:}

Anh Minh A.M. Tang, Yu-Jun Cui, Li-Xin Qian, Pierre Delage, Wei-Min Ye. Calibration of the osmotic technique of controlling suction with respect to temperature using a miniature tensiometer. Canadian Geotechnical Journal, 2010, 47, pp.359-365. hal-00539580

HAL Id: hal-00539580

https://hal.science/hal-00539580

Submitted on 24 Nov 2010

HAL is a multi-disciplinary open access archive for the deposit and dissemination of scientific research documents, whether they are published or not. The documents may come from teaching and research institutions in France or abroad, or from public or private research centers.
L'archive ouverte pluridisciplinaire HAL, est destinée au dépôt et à la diffusion de documents scientifiques de niveau recherche, publiés ou non, émanant des établissements d'enseignement et de recherche français ou étrangers, des laboratoires publics ou privés. 
Calibration of the osmotic technique of controlling suction with respect to temperature using a miniature tensiometer

\author{
Anh-Minh TANG ${ }^{1}$, Yu-Jun CUI ${ }^{1}$, Li-Xin QIAN ${ }^{1,2}$, Pierre DELAGE $^{1}$ and Wei-Min YE $^{2}$ \\ ${ }^{1}$ Ecole des Ponts - ParisTech, U.R. Navier - CERMES, 6 - 8 av. Blaise Pascal, Cité \\ Descartes, Champs - sur - Marne, 77455 MARNE - LA - VALLEE, France \\ ${ }^{2}$ Tongji University, 1239 road Siping, 200092 Shanghai, China
}

\title{
$\underline{\text { Corresponding author }}$
}

Prof. Yu-Jun CUI

Ecole des Ponts - ParisTech

$6-8$ av. Blaise Pascal, Cité Descartes, Champs - sur - Marne

77455 MARNE - LA - VALLEE

France

Phone : +33164153550

Fax : +33164153562

Email : cui@cermes.enpc.fr 


\section{Abstract}

The osmotic technique was calibrated at various temperatures $\left(20-40^{\circ} \mathrm{C}\right)$ using a highcapacity tensiometer. The effect of temperature on the calibration curve of the highcapacity tensiometer in the positive range has been found to be insignificant, about $0.03 \% /{ }^{\circ} \mathrm{C}$. The measurement at ambient temperature shows that the suction value is not significantly dependent on the molar mass of poly-ethylene glycol (PEG) nor on the molecular weight cut-off (MWCO) of the semi-permeable cellulose membrane. On the other hand, the matric suction measured in the present work by tensiometer was lower than the total suction found in the literature measured by psychrometer. This shows that the so-called membrane effects must be characterised by not only the crossing of PEG molecules but also other complex phenomena. The calibration at controlled temperatures showed a slight suction decrease by $1 \% /{ }^{\circ} \mathrm{C}$. One possible explanation for this decrease is that increasing temperature decreases the viscosity of PEG solutions, possibly accelerating the PEG molecules crossing. It is also possible that increasing temperature would change the physico-chemical properties of the PEG solutions, resulting in a suction decrease.

Keywords: Suction control, osmotic technique, temperature effect, high-capacity tensiometer, poly-ethylene glycol, calibration. 


\section{Introduction}

The effects of temperature changes on the hydro-mechanical behaviour of unsaturated soils are important in various geotechnical applications such as ground energy exploitation, stability of buried pipelines or power cables, radioactive waste disposal, impacts of climate change on the ground behaviour, etc. As the soils involved in such applications are often unsaturated, the laboratory investigation on the effects of temperature changes on their hydromechanical behaviour requires the use of techniques of controlling suction at various temperatures.

There are three mostly used techniques of controlling suction (Blatz et al. 2008): (i) vapour equilibrium technique (Tang and Cui, 2005); (ii) axis translation technique (Richards, 1941); and (iii) osmotic technique (see for instance Delage and Cui 2008a). The vapour equilibrium technique enables controlling the total suction through the relative humidity of a closed system containing in most cases a saturated saline solution and the soil specimen. After Delage et al. (1998), this technique presents significant uncertainties for suctions lower than $10 \mathrm{MPa}$. Oldecop and Alonso (2004) estimated that at a total suction of $10 \mathrm{MPa}$, an error of $1 \%$ in relative humidity (at $22{ }^{\circ} \mathrm{C}$ ) induced an error of $15 \%$ in terms of total suction. The accuracy of the vapour equilibrium technique at low suction range strongly depends on the control of the ambient temperature (Tang and Cui 2005). This technique has been used at high temperatures (up to $80^{\circ} \mathrm{C}$ ) to study the isothermal water retention curves (Lloret and Villar 2007) or to investigate the thermo-mechanical behaviour (Tang et al. 2008) of unsaturated compacted expansive clays.

The axis translation technique is usually used to control the matric suction for suctions lower than 1.5 MPa. An extension to $10 \mathrm{MPa}$ of suction was performed by Escario and Juca (1989). Romero et al. (2003) used this technique to study the thermo-hydromechanical behaviour of compacted Boom clay with the temperature ranging from 20 to $80{ }^{\circ} \mathrm{C}$. After Delage et al. (2008), there are some drawbacks in the use of the axis translation technique. On one hand, the application of an air pressure higher than the atmospheric pressure does not correspond to the field conditions. On the other hand, the applicability of the axis translation technique appears to be questionable at high degree of saturation when air is discontinuous and water is continuous in the soil pore network (Bocking and Fredlund 1980). Vanapalli et al. (2008) also reported that the theory associated with the axis translation technique is only valid for soils with totally interconnected pore-air voids and for soil particles that are incompressible and only when air-water inter-phase is continuous, which is typically the case for soils at a degree of saturation lower than $90 \%$.

In the osmotic technique, the soil specimen is placed in contact with a semi-permeable membrane behind which an aqueous solution of large sized molecules of polyethylene glycol (PEG) is circulated (Cui and Delage 1996, Delage and Cui 2008a). This technique was used to study the water retention properties of soils (Fleureau et al. 2002) and the hydromechanical behaviour of unsaturated soils (Kassiff and Ben Shalom 1971; Cui and Delage 1996; Cuisinier and Masrouri 2005; $\mathrm{Ng}$ et al. 2007). Although being most often used up to 1.5 $\mathrm{MPa}$, the osmotic technique has been extended to suctions up to $10 \mathrm{MPa}$ (Delage et al. 1998; Cuisinier and Masrouri 2005). Ghembaza et al. (2007) used the osmotic technique to control the soil suction up to $80^{\circ} \mathrm{C}$. These authors verified the temperature effect by examining the changes in refractometric index (Brix) of the PEG solutions with temperature changes and finally concluded that, for a given concentration, the imposed suction does not depend on the temperature.

The calibration of osmotic technique has been carried out at ambient temperature. Williams and Shaykewich (1969) demonstrated that the calibration curves of PEG solutions 
obtained with psychrometer measurements of the relative humidity of the solutions were independent on the PEG molecular mass. In order to calibrate the osmotic suction, Waldron and Manbeian (1970) used a null type osmometer in which the osmotic suction was compensated by an air pressure applied to the PEG solution. In the works of Peck and Rabbidge (1969) and Slatter et al. (2000), the osmotic suction was evaluated by measuring the pressure developed in PEG solutions at constant-volume conditions by putting them in contact with distilled water through a semi-permeable membrane. Beside these methods, soil suction can be also imposed on one side of a soil specimen using the osmotic technique while it is measured on the other side by high-capacity tensiometer (Dineen and Burland 1995; Tarantino and Mongiovi 2000; Monroy et al. 2007).

In the present work, the effect of temperature on the calibration curve of PEG solutions was investigated by measuring the matric suction generated by the PEG solution with a high-capacity tensiometer brought in contact with the semi-permeable membrane. Only a limited temperature range from 20 to $40^{\circ} \mathrm{C}$ was considered. The tests were performed with various molecular mass of PEG and with various membranes having different molecular weight cut-off values (MWCO). Note that the calibration of the osmotic technique at room temperature using a high-capacity tensiometer placed in contact with the semi-permeable membrane was performed by Dineen and Burland (1995) and Monroy et al. (2007). In their works, the PEG solution was circulated and this is not the case in the present study. This choice was based on the consideration that keeping the PEG solution inside the cell without any circulation allowed a good temperature control in all the system. Note also that Peck and Rabbidge (1969), Biesheuvel et al. (1999) studied the temperature effect on the osmotic pressure by sealing a PEG solution inside an osmotic tensiometer, in the range from 10 to $30{ }^{\circ} \mathrm{C}$. However, their works were on one PEG concentration only. In addition, to the authors' knowledge, the effects of PEG molar masse and MWCO of semi-permeable membrane on target suctions has not been reported yet.

\section{Experimental techniques}

The schematic view of the experimental device for calibrating the PEG solution is presented in Fig. 1. A high-capacity tensiometer (Cui et al. 2008) was fixed on the base of the calibration cell. A semi-permeable cellulose membrane (Spectrum) was then stuck on the surface of the base that was previously wetted. The upper part of the cell was subsequently installed and a PEG solution of known concentration was injected in the cell through the inlet. During the tests, the inlet of the cell was kept open to the atmosphere to ensure the atmospheric pressure conditions for the solution. Note that the inlet was small enough to allow the moisture exchange between the solution and the atmosphere to be neglected. For the calibration at controlled temperatures, the cell was immersed in a temperature-controlled bath with an accuracy of $\pm 0.1^{\circ} \mathrm{C}$ similar to that used by Tang et al. (2007).

The system shown in Fig. 1 was also used for the calibration of the high-capacity tensiometer. For this purpose, the cell was filled with distilled water and the pressure of water in the cell was imposed using a high accuracy Pressure/Volume Controller (CPV, $\pm 1 \mathrm{kPa})$. The CPV was connected to the cell by metal tubing of $1 \mathrm{~m}$ long. It was assumed that the pressure imposed by the CPV was not affected by the temperature applied to the cell. Actually, as there was no significant water flow between the CPV and the cell, the heat transfer by convection can be neglected. Furthermore, the metal tubing has been regarded as long enough for also neglecting the heat diffusion from the cell to the CPV. Thus the pressure imposed by the CPV can be assumed to not be affected by the temperature applied to the cell. The tensiometer was calibrated in the positive pressures range and the calibration curve in the 
negative pressures was extrapolated. This procedure is similar to that described by Tarantino and Mongiovi (2001). The results on the tensiometer calibration are shown in Fig. 2. In Fig. $2 b$, the signal $U_{t}$ of the tensiometer was plotted versus the pressure applied by the CPV for the calibration at $25^{\circ} \mathrm{C}$, giving the following linear relationship:

$$
U_{t}=-1.0901 \times 10^{-3} p-5.7948 \times 10^{-1}
$$

with $U_{t}$ in $\mu \mathrm{V}$ and the pressure applied $(p)$ in $\mathrm{kPa}$.

The same calibration procedure was applied for higher temperatures $\left(30,35\right.$ and $\left.40^{\circ} \mathrm{C}\right)$. The signals obtained allowed calculating the equivalent pressures at $25^{\circ} \mathrm{C}$ using Eq. (1), and these pressures were then compared with that imposed by the CPV at different temperatures. The difference between the calculated and the imposed pressures are regarded as errors that is presented in Fig. $2 a$ versus the imposed pressure. It can be noted that the effect of temperature on the tensiometer calibration curves was not significant. For instance, at $p$ equal to $2000 \mathrm{kPa}$, the difference between the pressure measured at $40^{\circ} \mathrm{C}$ and that at $25^{\circ} \mathrm{C}$ was $10 \mathrm{kPa}(0.5 \%)$. This corresponds to a change of $0.03 \% /{ }^{\circ} \mathrm{C}$.

The experimental program is shown in Table 1. Tests $\mathrm{C} 01-\mathrm{C} 15$ were performed at ambient temperature of $21 \pm 1^{\circ} \mathrm{C}$ without using any temperature-controlled bath. For tests $\mathrm{C} 16$ and $\mathrm{C} 17$, the cell was immersed in the temperature-controlled bath. The temperature was fixed initially at $25^{\circ} \mathrm{C}$ until reaching suction equilibrium as indicated by the tensiometer. Actually, the temperature of the bath was controlled by a thermostat pump which can only heat water when its temperature is $0.1{ }^{\circ} \mathrm{C}$ lower than the target value. The minimum temperature of the bath should be then always higher than the ambient temperature. This explains the initial temperature of the bath fixed at $25^{\circ} \mathrm{C}$. After suction equilibrium, the temperature was then increased in steps to 30,35 and $40{ }^{\circ} \mathrm{C}$. For each step, a duration of about 0.5 hour was needed for the stabilisation of suction. No temperatures higher than $40{ }^{\circ} \mathrm{C}$ was considered because this temperature corresponds to the limit for the use of the highcapacity tensiometer: the strain gages of the tensiometer would be unstuck from the diaphragm under higher temperatures. In addition, compared to the tests at ambient temperature, a lower concentration of PEG solution was chosen in the controlled temperature tests $(13.7 \mathrm{~g} / 100 \mathrm{ml})$. This choice aimed at avoiding the tensiometer cavitation. Indeed, following the cavitation mechanisms described by Tarantino and Mongiovi (2001), the conditions of the temperature-controlled tests (high temperature and long duration) favour the cavitation occurrence. Furthermore, it has been concluded that the higher the suction the earlier the cavitation.

\section{Results}

The responses of tensiometer for tests $\mathrm{C} 01-\mathrm{C} 10$ are plotted in Fig. 3 in terms of changes in suction measured by the tensiometer versus the elapsed time. These tests were performed with PEG solutions having a concentration of $19.5 \mathrm{~g}$ PEG/100ml water within various values of MWCO for the membranes. In this figure, time zero corresponds to the time when the PEG solution was injected in the cell. All the curves show that the suction started to increase after around $0.1 \mathrm{~h}$. For tests $\mathrm{C} 05, \mathrm{C} 09$, and $\mathrm{C} 10$, the suction increased quickly, reached its maximum values after $0.3 \mathrm{~h}$ and then decreased slightly. For the other tests, the suction increased continuously and reached equilibrium after $1 \mathrm{~h}$. The maximum values of suction measured for all these tests vary from 310 to $390 \mathrm{kPa}$.

In Fig. 4, the results of tests $\mathrm{C} 11-\mathrm{C} 15$ are plotted. All these tests were performed by using PEG20000 with a concentration of $23.7 \mathrm{~g}$ PEG/100ml water. For tests C11, C12, and $\mathrm{C} 15(\mathrm{MWCO}=12000-14000)$, the suction started to increase after $0.10 \mathrm{~h}$ and reached the 
equilibrium value of $540 \mathrm{kPa}$ after $1 \mathrm{~h}$. For tests $\mathrm{C} 13$ and $\mathrm{C} 14(\mathrm{MWCO}=3500)$, the suction started to increased after $0.15 \mathrm{~h}$ and reached equilibrium at a value of $560 \mathrm{kPa}$ after $1 \mathrm{~h}$. As the results for the same PEG concentration but various values of MWCO and PEG masses are presented in the same figure ( $19.5 \mathrm{~g} / 100 \mathrm{ml}$ in Fig. 3 and $23.7 \mathrm{~g} / 100 \mathrm{ml}$ in Fig. 4), the effects of the membrane or the PEG molecular weight on the suction changes versus time can be directly appreciated.

In Fig. 5, the suction measured after $1 \mathrm{~h}$ in tests $\mathrm{C} 01-\mathrm{C} 15$ run at ambient temperature is plotted versus the MWCO of the semi-permeable membrane used. Three membranes with MWCO equal to 1500, 3500, and 12000 respectively were used with two PEG 20000 concentrations. The results show a very slight decrease of suction measured with larger values of MWCO. For PEG 6000, the difference between the results obtained with the two membranes (MWCO 1500 and 3500 respectively) is also found to be not significant. With a concentration of $19.5 \mathrm{~g}$ PEG/100ml water, the suctions obtained with PEG6000 are slightly higher than that obtained with PEG20000. In Fig. 5, the suctions calculated following the calibrations proposed by Williams and Shaykewich (1969) and by Dineen and Burland (1995) are also plotted. It can be seen that the results obtained in this work are comparable to that of Dineen and Burland (1995), who also performed tensiometer measurements with PEG 20000 and a MWCO 14000 membrane.

The results of tests $\mathrm{C} 16$ and $\mathrm{C} 17$, performed under temperature controlled conditions with a PEG 20000 concentration of $13.7 \mathrm{~g}$ PEG/100ml water are plotted in Fig. 6. Note that the calibration curve of the tensiometer (signal received in $\mu \mathrm{V}$ versus the imposed pressure in $\mathrm{kPa}$ ) was slightly influenced by the temperature changes (see Fig. 2). For this reason, the signal was plotted versus the elapsed time. For both tests, the signal started to change quickly after $0.15 \mathrm{~h}$. This corresponds to the change in suction measured from 0 towards the equilibrium value observed previously (see Fig. 3 and Fig. 4). The signal reached its equilibrium value at $25{ }^{\circ} \mathrm{C}$ after $1 \mathrm{~h}$. When increasing the temperature of the calibration cell from 25 to $30^{\circ} \mathrm{C}$, the signal (and also the corresponding suction) firstly decreased and then increased to reach again the equilibrium state after about $0.5 \mathrm{~h}$. A similar response was observed in the other heating steps.

The suction values obtained at equilibrium corresponding to each temperature are plotted in Fig. 7. These suction values were calculated from the signal obtained during the tensiometer calibration presented in Fig. 2, in which temperature effects were taken into account. The results show a slight decrease of suction by about $1 \% /{ }^{\circ} \mathrm{C}$ when the temperature increased from 25 to $40^{\circ} \mathrm{C}$. The suctions estimated from the calibration curves of Williams and Shaykewich (1969) and Dineen and Burland (1995) are also presented. In the lack of relevant information, the ambient temperature in these works was assumed to be $20{ }^{\circ} \mathrm{C}$.

\section{Discussion}

Hoffman et al. (2006) studied the effect of temperature on the calibration of a high-capacity tensiometer. The results showed that the slope of the calibration line slightly changed with temperature (less than 2\%) but it appeared that the intercept of the calibration line was significantly influenced by temperature changes (in the range of $100 \mathrm{kPa}$ for $\mathrm{T}=20-40{ }^{\circ} \mathrm{C}$ ). In the present work, the effect of temperature on the tensiometer was about $0.03 \% /{ }^{\circ} \mathrm{C}$. This value is negligible when compared to the effect of temperature on the suction generated by the PEG solution $\left(1 \% /{ }^{\circ} \mathrm{C}\right)$.

The tensiometer responses (Fig. 3, Fig. 4, and Fig. 6) showed that a few minutes were required to obtain a relevant suction measurement. This duration is similar to that observed by 
Peck and Rabbidge (1969) and Dineen and Burland (1995) who used also a cellulose membrane. By contrast, several days appeared to be needed when using a poly-ether sulfonate ultra filtration (PES-UF) synthetic membrane (Monroy et al. 2007).

The calibration results obtained in Fig. 5 were similar to that obtained by Dineen and Burland (1995) and showed a lower suction than that measured by Williams and Shaykewich (1969). When using the PES-UF synthetic membrane (Monroy et al. 2007) the suction obtained was higher and close to that of Williams and Shaykewich (1969). The lower suction measured when using cellulose membrane has been attributed to the membrane effects (Dineen and Burland 1995, Delage and Cui 2008b): some quantity of PEG molecules is suspected to have crossed the membrane. Nevertheless, the results of this work show that the effect of the molecular mass and thus the molecules size is not significant (Fig. 5). Indeed, Delage and Cui (2008b) reported that a few PEG molecules cross the membrane when appropriate cellulose membrane is used in terms of MWCO values. The membrane effects must be characterised by other more complex phenomena.

The response of the high-capacity tensiometer upon heating (subsequent decrease and then increase of suction) shown in Fig. 6 can be explained as follows: the suction generated by the PEG solution and the membrane creates a tension in the water stored in the porous stone and in the water reservoir of the tensiometer (see Cui et al., 2008, for the schematic view of the tensiometer); heating firstly induced the dilation of this volume of water resulting in a reduction of the water tension; as a result the suction measured by the tensiometer also decreased. With time the measured suction increased to reach the equilibrium with the imposed suction at the new temperature.

From the results of temperature-controlled tests shown in Fig. 7, a suction of $150 \mathrm{kPa}$ can be extrapolated for the ambient temperature $\left(20^{\circ} \mathrm{C}\right)$. This value is similar to that of Dineen and Burland (1995). That is also in agreement with the results of higher suctions shown in Fig. 5.

The temperature effect on the suction generated by the osmotic technique was identified: the suction decreased approximately by $1 \% /{ }^{\circ} \mathrm{C}$ when the temperature was increasing. This value is in the same order of magnitude of that found in the literature with osmotic tensiometer: Peck and Rabbidge (1969) observed that the osmotic pressure decreased by $1.5 \% /{ }^{\circ} \mathrm{C}$ when the temperature increased from 10 to $30^{\circ} \mathrm{C}$ and Biesheuvel et al. (1999) identified $3 \% /{ }^{\circ} \mathrm{C}$ for the temperature comprised between 23 and $24^{\circ} \mathrm{C}$. This suction decrease with increasing temperature is difficult to be explained. One of the possible explanations could be based on the consideration of a small quantity of PEG molecules that crossed the cellulose membrane (see Delage and Cui 2008b): heating decreased the viscosity of the solutions and therefore the quantity of the PEG molecules which cross the membrane would be more significant, giving rise to a decrease in suction. As mentioned above, the membrane effects are complex and they are not limited to the PEG molecules crossing. It is probable that heating changes some of the membrane effects. Moreover, it would be also possible that heating changes the physico-chemical properties of the PEG solutions due to the difference of thermal dilation between water and PEG molecules or due to the chemical changes of PEG molecules themselves. Further studies are needed to investigate these points more deeply.

For the tests at ambient temperature (Fig. 5), the reliability can be affected by the two factors: the reliability of the tensiometer used and the precision of the PEG concentration prepared. On the contrary, for the temperature-controlled tests, the effects of these factors can be neglected because the suctions at different temperatures were measured with the same tensiometer and the same PEG solution. Therefore, a high reliability could be attributed to the identified temperature effects. 


\section{Conclusions}

The suction generated by the osmotic technique was measured by keeping a high-capacity tensiometer in contact with the cellulose semi-permeable membrane. The tests at ambient temperature $\left(21^{\circ} \mathrm{C}\right)$ were carried out with two values of PEG molar mass (6000 and 20000) and three values of molecular weight cut-off (MWCO) for the semi-permeable membrane. In addition, two temperature-controlled tests $\left(25,30,35,40^{\circ} \mathrm{C}\right)$ were performed with PEG 20000 and two types of membrane (MWCO 1000 and 12000). The following conclusions can be drawn from the experimental observations.

i) The effect of temperature on the calibration curve of the high-capacity tensiometer in the positive range has been found to be insignificant, about $0.03 \% /{ }^{\circ} \mathrm{C}$.

ii) The use of cellulose membrane allowed a short response time (few minutes) for the suction measurement using the high-capacity tensiometer. The response time was found to be much longer (several days) when using a poly-ether sulfonate ultra filtration (PES-UF) synthetic membrane (Monroy et al. 2007).

iii) As the suctions obtained in this study using high-capacity tensiometers are lower than that measured by Williams and Shaykewich (1969) using psychrometers, the membrane effects have been suspected. On the other hand, the effects of the size of PEG molecules and the semi-permeable membrane seem to be negligible. It appears therefore that the so-called membrane effects must be characterised by not only the crossing of PEG molecules but also other more complex phenomena.

iv) The measured suction decreased approximately by $1 \% /{ }^{\circ} \mathrm{C}$ when the temperature was increasing. This temperature effect could be again attributed to a possibly accelerated PEG molecules crossing or to the changes in other more complex phenomena as membrane effects, physico-chemical changes of the PEG solutions. More tests should be carried out to better quantify the effects of temperature on suction.

\section{Acknowledgements}

The authors are grateful to the National Natural Science Foundation of China for its supports (No 40728003).

\section{References}

Biesheuvel, P.M., Raangs, R. and Verweij, H. 1999. Response of the osmotic tensiometer to varying temperatures: modelling and experimental validation. Soil Sci. Soc. Am. J., 63: $1571-1579$.

Blatz J., Cui Y.J. and Oldecop L. 2008. Vapour Equilibrium and Osmotic Technique for Suction Control. Geotechnical and Geological Engineering, Special Issue on "Laboratory and Field Testing of Unsaturated Soils". Online (doi: 10.1007/s10706-008-9196-1).

Bocking, K.A., and Fredlund, D.G. 1980. Limitations of the axis translation technique. Proc. $4^{\text {th }}$ Int. Conf. on Expansive Soils, Denver, Colorado, $117-135$.

Cui, Y.J. and Delage, P. 1996. Yielding and plastic behaviour of an unsaturated compacted silt. Géotechnique, 46(2): 291-311. 
Cui, Y.J., Tang, A.M., Mantho, A.T. and E. De Laure. 2008. Monitoring field soil suction using a miniature tensiometer. Geotechnical Testing Journal, 31(1): 95-100.

Cuisinier, O. and Masrouri, F. 2005. Hydromechanical behaviour of a compacted swelling soil over a wide suction range. Engineering Geology, 81(3): 204-212.

Delage, P., Howat, M. and Cui, Y.J. 1998. The relationship between suction and swelling properties in a heavily compacted unsaturated clay. Engineering Geology, 50(1-2): 31-48.

Delage, P. and Cui, Y.J. 2008a. An evaluation of the osmotic method of controlling suction. Geomechanics and Geoengineering: An International Journal, 3(1): 1-11.

Delage, P. and Cui, Y.J. 2008b. A novel filtration system for polyethylene glycol solutions used in the osmotic method of controlling suction. Canadian Geotechnical Journal, 45(3): 421-424.

Delage, P., Romero, E. and Tarantino, A. 2008. Recent developments in the techniques of controlling and measuring suction in unsaturated soils. Unsaturated soils: Advances in Geo-Engineering - Toll et al. (eds), 33 - 52.

Dineen, K. and Burland, J.B. 1995. A new approach to osmotically controlled oedometer testing. In Proceedings of 1st Conference on Unsaturated Soils (UNSAT'95), Paris, 6-8 September 1995. Edited by E.E. Alonso and P. Delage. A.A. Balkema, Rotterdam, the Netherlands. Vol. 2, 459-465.

Escario, V. and Juca, F. 1989. Strength and deformation of partly saturated soils. Proc. $12^{\text {th }}$ Int. Conf. Soils Mech. Found. Engineering, Rio de Janeiro, 13 - 18 August 1989. A.A. Balkema, Rotterdam, the Netherlands, Vol. 1, 43 - 46.

Fleureau, J.M., Verbrugge, J.C., Huergo, P.J., Correia, A.G. and Siba, K.S. 2002. Aspects of the behaviour of compacted clayey soils on drying and wetting paths. Canadian Geotechnical Journal, 39(6): 1341-1357.

Ghembaza, M.S., Ta ï bi, S. and Fleureau, J.M. 2007. Effet de la température sur le comportement des sols non saturés sur les chemins de drainage et d'humidification Canadian Geotechnical Journal 44(9): 1061-1081.

Hoffmann, C. Tarantino, A. and Mongiovi, L. 2006. Thermal effects on response of high suction tensiometer. Proc. $4^{\text {th }}$ Int. Conf. Unsaturated Soils, Geotechnical Special Publication 147: 1887-1896.

Kassiff, G. and Ben Shalom A. 1971. Experimental relationship between swell pressure and suction. Géotechnique, 21: 245-255.

Lloret, A. and Villar, M.V. 2007. Advances on the knowledge of thermo-hydro-mechanical behaviour of heavily compacted FEBEX bentonite. Physics and Chemistry of the Earth, 32: 701-715.

Monroy, R., Ridley, A., Dineen, K. and Zdrakovic, L. 2007. The suitability of osmotic technique for the long term testing of partly saturated soils. Geotechnical Testing Journal, 30(3): 220-226.

Ng, C.W.W., Cui, Y., Chen, R. and Delage, P. 2007. The axis-translation and osmotic techniques in shear testing of unsaturated soils: a comparison. Soils and Foundations, 47(4): 675-684.

Oldecop, L.A. and Alonso, E.E. 2004. Testing Rockfill under Relative Humidity Control. Geotechnical Testing Journal, 27(3): 269 - 278.

Peck, A.J. and Rabbidge, R.M. 1969. Design and performance of an osmotic tensiometer for measuring capillary potential. Soil Science Society American Proceedings, 33: 196-202.

Richards, L.A. 1941. A pressure-membrane extraction apparatus for soil solution. Soil Science, 51: 377 - 386.

Romero, E., Gens, A. and Lloret, A. 2003. Suction effects on a compacted clay under nonisothermal conditions. Géotechnique, 53(1): 65-81. 
Slatter, E.E., Jungnickel, C.A., Smith, D.W., and Allman, M.A. 2000. Inverstigation of suction generation in apparatus employing osmotic methods. In Unsaturated Soils for Asia: Proceedings of the Asian Conference on Unsaturated soils (UNSAT-ASIA 2000), Singapore, 18 - 19 May 2000. Edited by H. Rahardjo, D.G.Toll, and E.C. Leong. Belkema, Rotterdam, the Netherlands, $297-302$.

Tang, A.M. and Cui, Y.J. 2005. Controlling suction by the vapour equilibrium technique at different temperatures and its application in determining the waer retention properties of MX80 clay. Canadian Geotechnical Journal, 42(1): 287-296.

Tang, A.M., Cui, Y.J. and Barnel, N. 2007. A new isotropic cell for studying the thermomechanical behavior of unsaturated expansive clays. Geotechnical Testing Journal, 30(5): 341-348.

Tang, A.M., Cui, Y.J. and Barnel, N. 2008. Thermo-mechanical behaviour of a compacted swelling clay. Géotechnique, 58(1): 45-54.

Tarantino, A. and Mongiovi, L. 2000. A study of the efficiency of semi-permeable membranes in controlling soil matrix suction using the osmotic technique. In Unsaturated Soils for Asia: Proceedings of the Asian Conference on Unsaturated soils (UNSAT-ASIA 2000), Singapore, 18 - 19 May 2000. Edited by H. Rahardjo, D.G.Toll, and E.C. Leong. Belkema, Rotterdam, the Netherlands, 303-308.

Tarantino, A. and Mongiovi, L. 2001. Experimental procedures and cavitation mechanisms in tensiometer measurements. Geotechnical and Geological Engineering, 19: 189-210.

Vanapalli, S.K., Nicotera, M.V., Sharma, R.S. 2008. Axis translation and negative water column techniques for suction control. Geotechnical and Geological Engineering, 26(6): 645-660.

Waldron, L.J. and Manbeian, T. 1970. Soil moisture characteristics by osmosis with polyethylene glycol: a simple system with osmotic pressure data and some results. Soil Science, 110(6): $401-404$.

Williams, J. and Shaykewich, C.F. 1969. An evaluation of polyethylene glycol PEG 6000 and PEG 20000 in the osmotic control of soil water matrix potential. Canadian Journal of Soil Science, 102(6): 394-398. 


\section{Liste of figures captions}

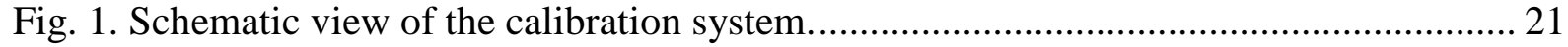

Fig. 2. Calibration of tensiometer at controlled temperatures............................................. 22

Fig. 3. Tests at ambient temperature for concentration of $19.5 \mathrm{~g} / 100 \mathrm{ml}$ water. Response of

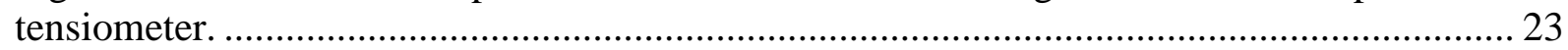

Fig. 4. Tests at ambient temperature for concentration of $23.7 \mathrm{~g} / 100 \mathrm{ml}$ water. Response of

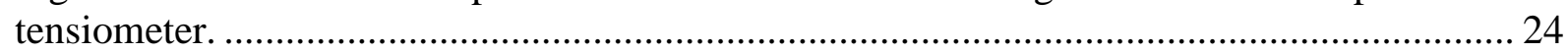

Fig. 5. Tests at ambient temperature. Suction versus MWCO........................................ 25

Fig. 6. Tests at temperature controlled. Response of tensiometer......................................... 26

Fig. 7. Tests at temperature controlled. Suction versus temperature. .................................... 27 
Table 1. Experimental program

\begin{tabular}{|c|c|c|c|c|c|}
\hline $\begin{array}{l}\text { Test } \\
\text { No. }\end{array}$ & $\begin{array}{l}\text { Molecular } \\
\text { mass } \\
\text { of PEG }\end{array}$ & $\begin{array}{l}\text { MWCO } \\
\text { of membrane }\end{array}$ & $\begin{array}{l}\text { Concentration } \\
(\mathrm{g} / 100 \mathrm{ml})\end{array}$ & $\begin{array}{l}\text { Suction }(\mathrm{kPa}) \\
\text { (Williams and } \\
\text { Shaykewich } \\
\text { 1969) }\end{array}$ & $\begin{array}{l}\text { Temperature } \\
\left({ }^{\circ} \mathrm{C}\right)\end{array}$ \\
\hline $\mathrm{C} 01$ & 20000 & 1000 & 19.5 & 427 & $21 \pm 1^{\circ} \mathrm{C}$ \\
\hline $\mathrm{C} 02$ & 20000 & 3500 & 19.5 & 427 & $21 \pm 1^{\circ} \mathrm{C}$ \\
\hline $\mathrm{C} 03$ & 20000 & $12000-14000$ & 19.5 & 427 & $21 \pm 1^{\circ} \mathrm{C}$ \\
\hline $\mathrm{C} 04$ & 6000 & 1000 & 19.5 & 427 & $21 \pm 1^{\circ} \mathrm{C}$ \\
\hline $\mathrm{C} 05$ & 6000 & 3500 & 19.5 & 427 & $21 \pm 1^{\circ} \mathrm{C}$ \\
\hline $\mathrm{C} 06$ & 20000 & 1000 & 19.5 & 427 & $21 \pm 1^{\circ} \mathrm{C}$ \\
\hline $\mathrm{C} 07$ & 20000 & 3500 & 19.5 & 427 & $21 \pm 1^{\circ} \mathrm{C}$ \\
\hline $\mathrm{C} 08$ & 20000 & $12000-14000$ & 19.5 & 427 & $21 \pm 1^{\circ} \mathrm{C}$ \\
\hline $\mathrm{C} 09$ & 6000 & 1000 & 19.5 & 427 & $21 \pm 1^{\circ} \mathrm{C}$ \\
\hline $\mathrm{C} 10$ & 6000 & 3500 & 19.5 & 427 & $21 \pm 1^{\circ} \mathrm{C}$ \\
\hline $\mathrm{C} 11$ & 20000 & $12000-14000$ & 23.7 & 689 & $21 \pm 1^{\circ} \mathrm{C}$ \\
\hline $\mathrm{C} 12$ & 20000 & $12000-14000$ & 23.7 & 689 & $21 \pm 1^{\circ} \mathrm{C}$ \\
\hline $\mathrm{C} 13$ & 20000 & 3500 & 23.7 & 689 & $21 \pm 1^{\circ} \mathrm{C}$ \\
\hline $\mathrm{C} 14$ & 20000 & 3500 & 23.7 & 689 & $21 \pm 1^{\circ} \mathrm{C}$ \\
\hline $\mathrm{C} 15$ & 20000 & $12000-14000$ & 23.7 & 689 & $21 \pm 1^{\circ} \mathrm{C}$ \\
\hline $\mathrm{C} 16$ & 20000 & $12000-14000$ & 13.7 & 212 & $25 / 30 / 35 / 40^{\circ} \mathrm{C}$ \\
\hline C17 & 20000 & 1000 & 13.7 & 212 & $25 / 30 / 35 / 40^{\circ} \mathrm{C}$ \\
\hline
\end{tabular}




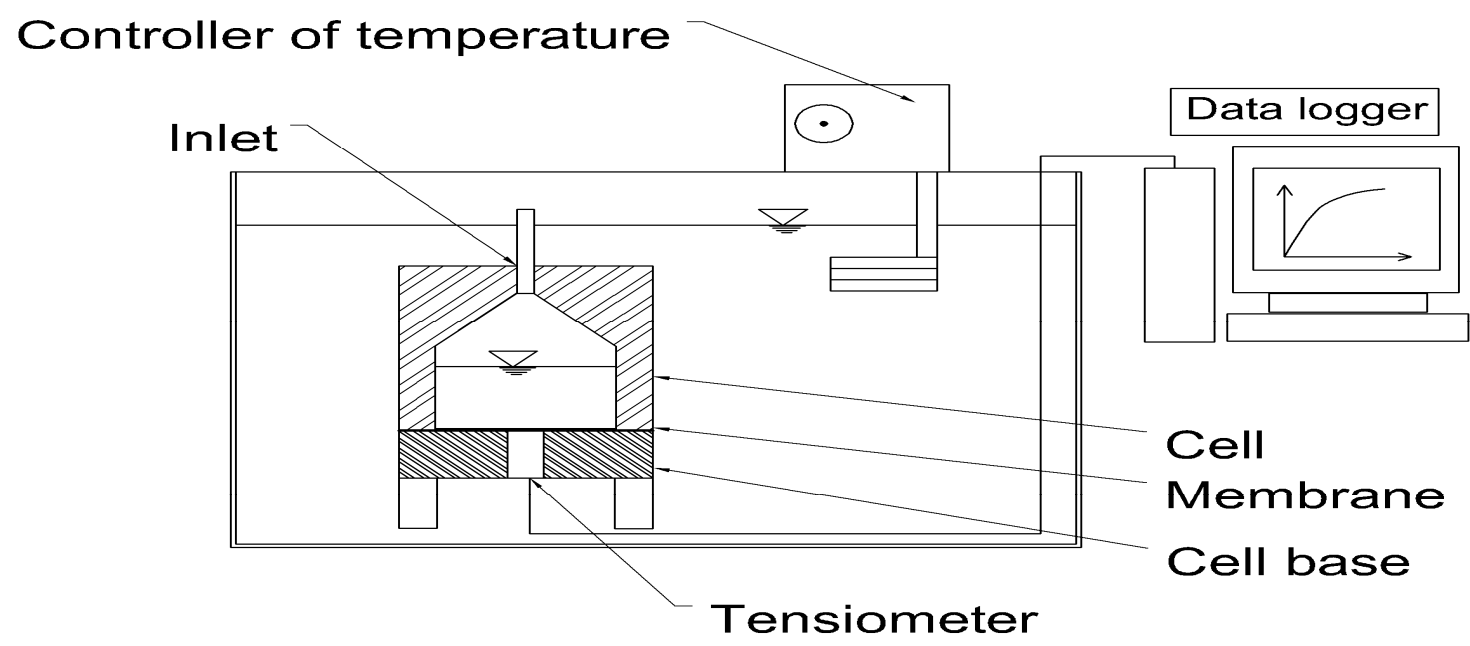

Fig. 1. Schematic view of the calibration system. 


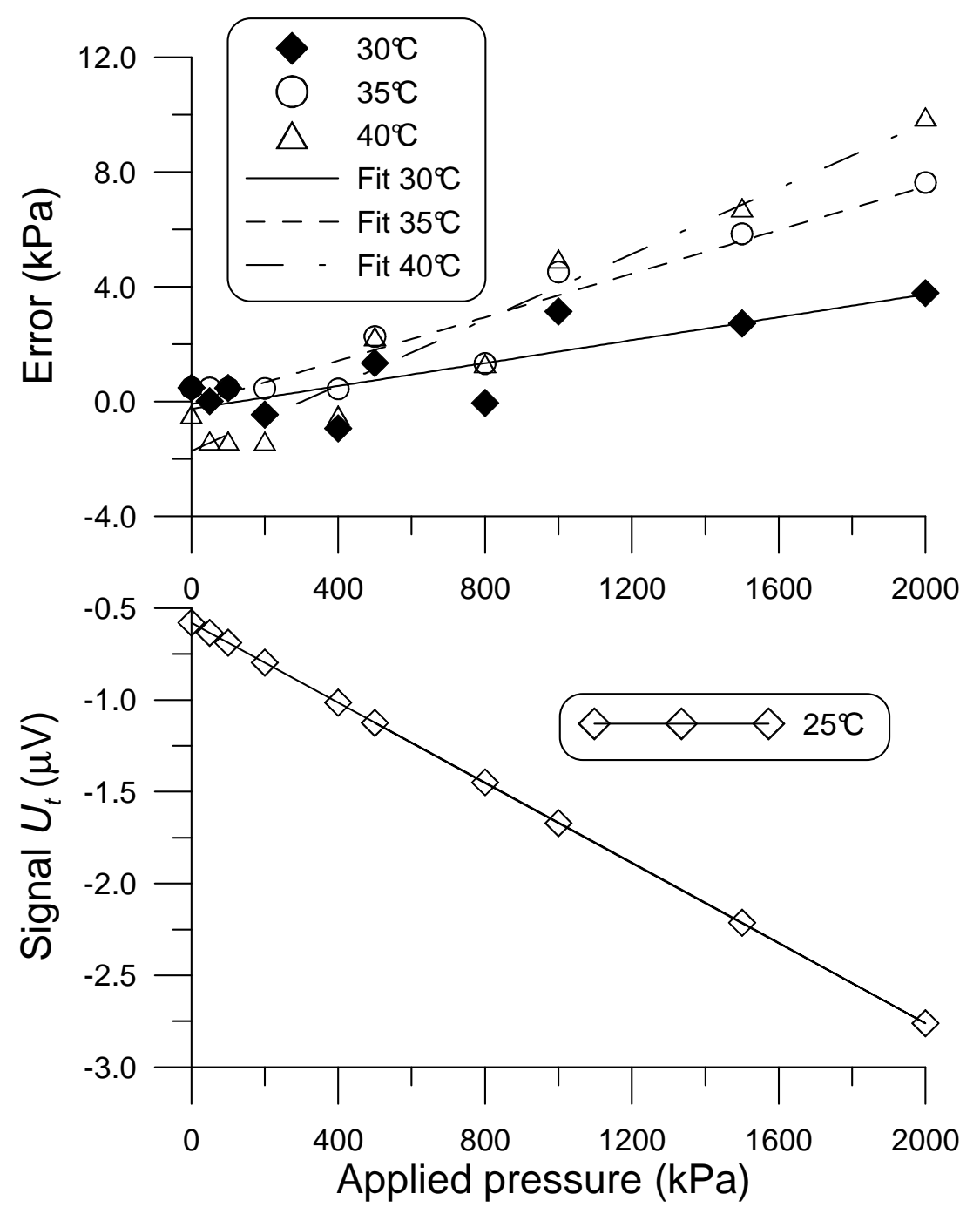

(a)

(b)

Fig. 2. Calibration of tensiometer at controlled temperatures. 


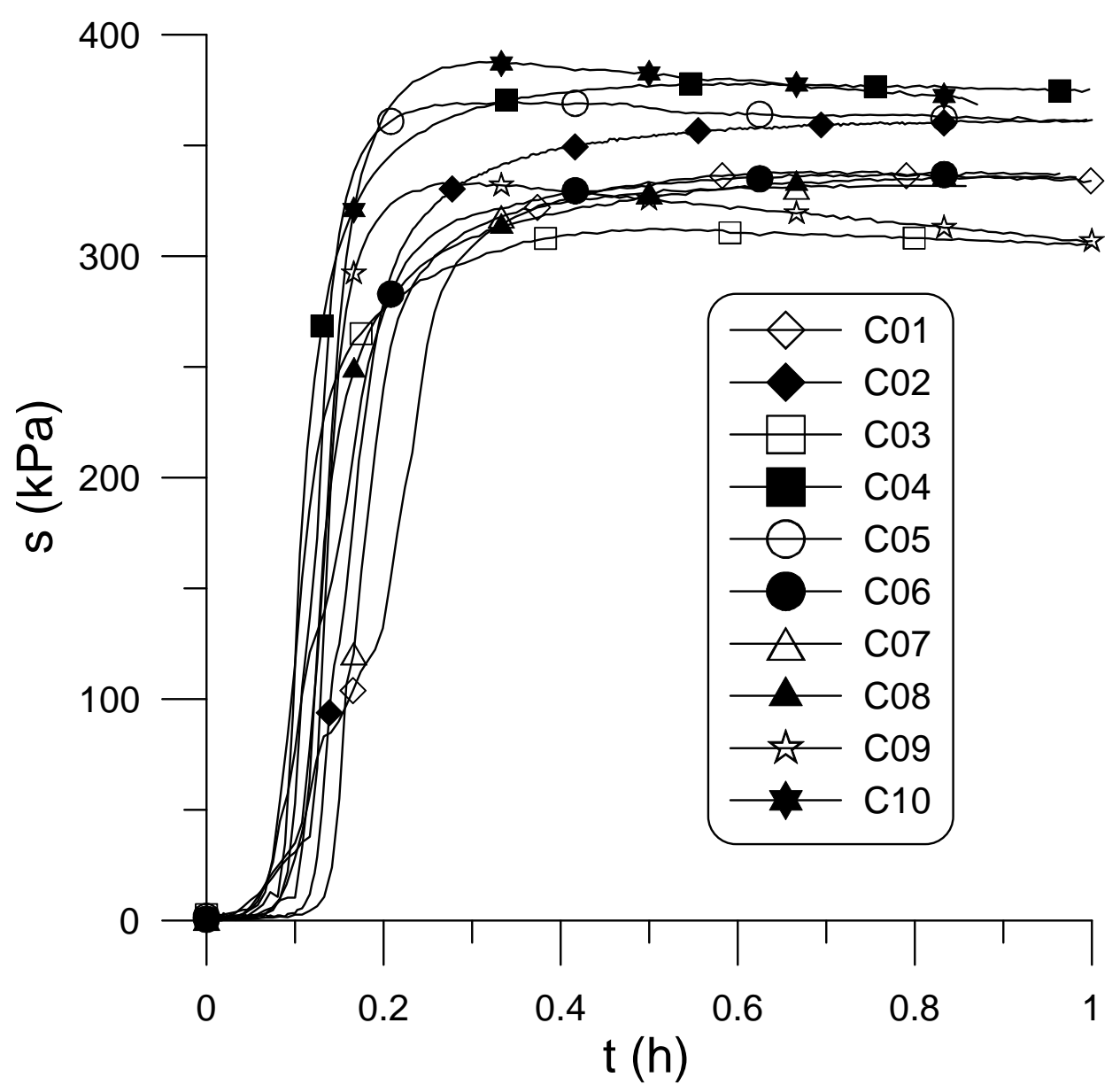

Fig. 3. Tests at ambient temperature for concentration of $19.5 \mathrm{~g} / 100 \mathrm{ml}$ water. Response of tensiometer. 


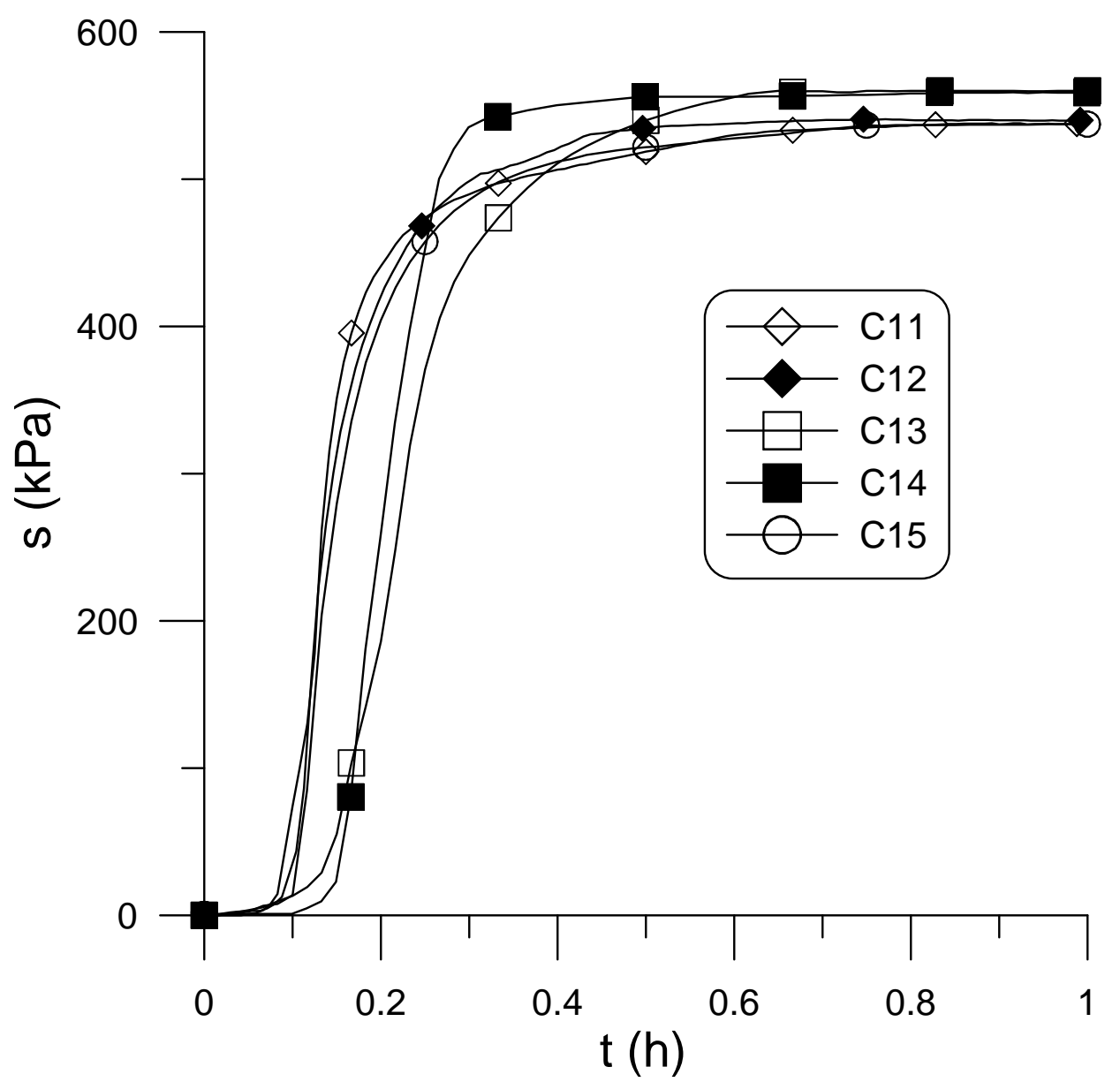

Fig. 4. Tests at ambient temperature for concentration of $23.7 \mathrm{~g} / 100 \mathrm{ml}$ water. Response of tensiometer. 
$\times \quad$ PEG20000

$\bigcirc$ PEG6000

Williams and Shaykewich (1969)

- - - Dineen and Burland (1995)

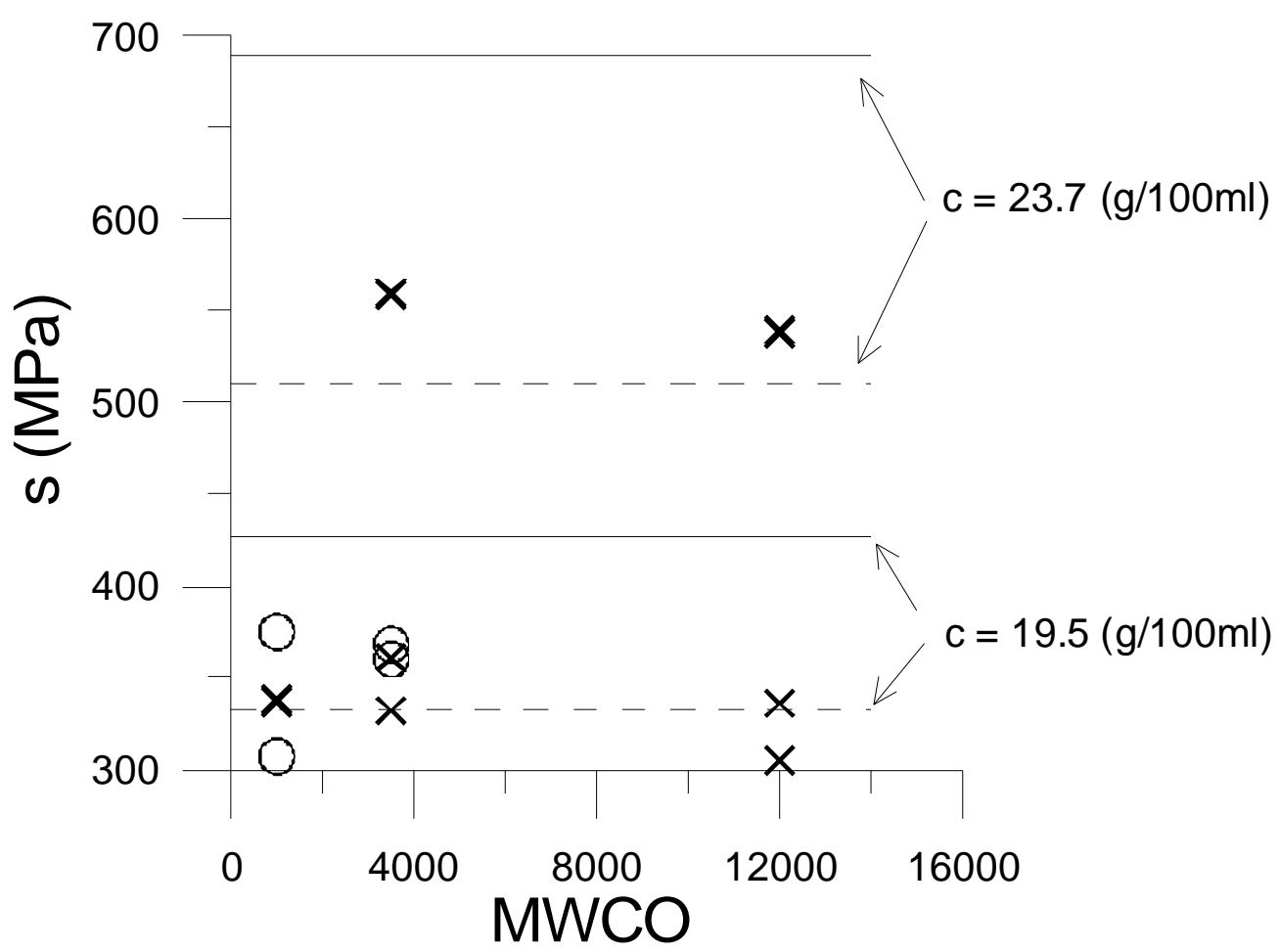

Fig. 5. Tests at ambient temperature. Suction versus MWCO. 


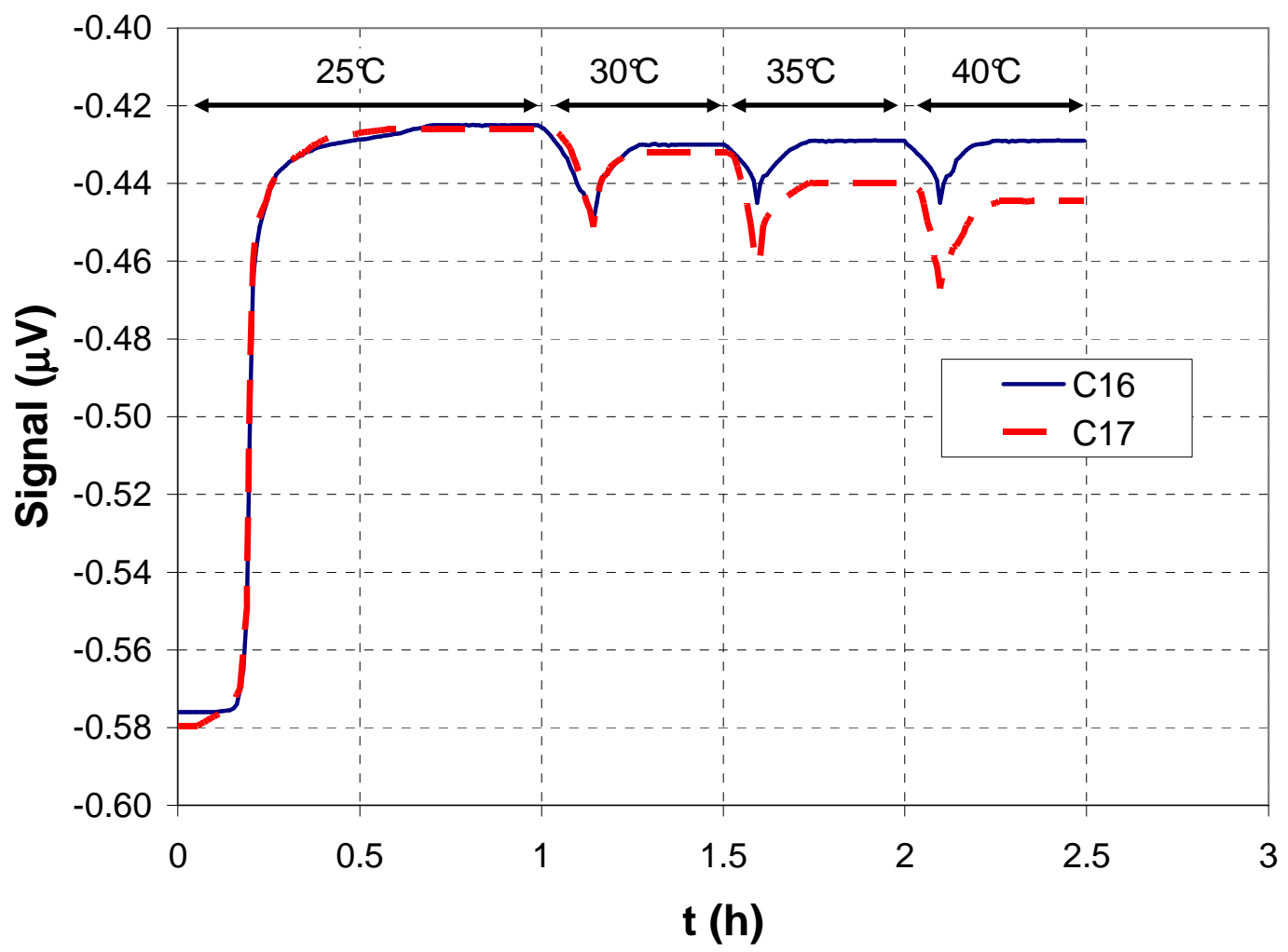

Fig. 6. Tests at temperature controlled. Response of tensiometer. 


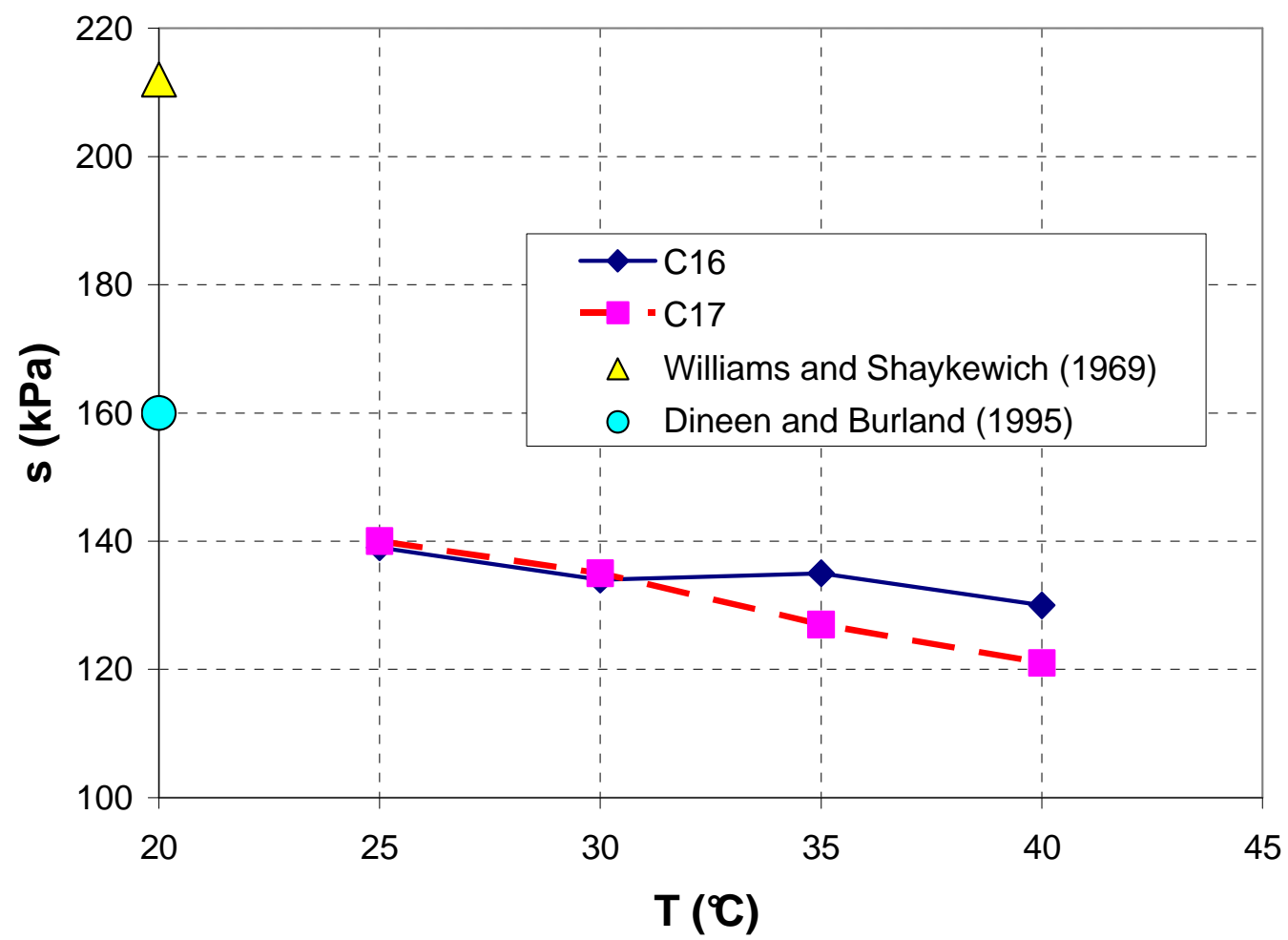

Fig. 7. Tests at temperature controlled. Suction versus temperature. 